\title{
Degree-Day and Bin Methods of Estimating Cooling Energy for Ilorin Area of Kwara State, Nigeria
}

\author{
D.O. Ariyo ${ }^{1}$, J.A. Olorunmaiye ${ }^{2}$ \\ 1. Department of Mechanical Engineering, Federal Polytechnic, Offa, Nigeria. \\ 2. Department of Mechanical Engineering, University of Ilorin, Nigeria
}

\begin{abstract}
The values for cooling degree-day and bin were computed from hourly ambient dry bulb temperature data of 15years (1978-1992) for Ilorin. Cooling degree-day values at 24, 25, 26,27,28,29 and $30^{\circ} \mathrm{C}$ base temperatures were computed from the long-term (15 years) hourly ambient dry bulb temperatures. Values predicted with the model developed for cooling degree-day agreed closely with those computed from hourly temperature data. Bin data were computed from the data of 15 years hourly ambient dry bulb temperature for the same period. Bin width of $I^{\circ} C$ was used in computing the bin data. Monthly and annual bin data are presented in tables and on graphs. Energy analysis of a sample building (workshop) in Ilorin was performed using the degree-day and bin values obtained in this study. Annual cooling energy requirement obtained using bin method is higher than that of degree-day method. The real energy requirement could be somewhere between the values obtained using degee-day and bin methods.
\end{abstract}

Keywords: Cooling degree-day, Bin data, Dry bulb temperature, cooling energy.

\section{Introduction}

Degree-day is the accumulation of one-sided differences between a base value of temperature and the set of values of temperature which occur. Heating degree-day is the sum of all positive differences between the base temperature $\left(T_{b}\right)$ and the observed values of ambient temperature $\left(T_{o}\right)$ i.e. $\left(T_{b}-T_{0}\right)$, whereas cooling degree-day is the accumulation of positive differences between observed values of temperature and the base temperature i.e. $\left(\mathrm{T}_{\mathrm{o}}-\mathrm{T}_{\mathrm{b}}\right)$ ( Erbs, 1984; Ariyo, 1997).

Bin data can be compiled from long-term hourly ambient dry bulb temperature. They are often reported as the number of hours a temperature was in each bin. A temperature range has to be chosen and divided into a number of intervals (bins) and the fraction of the month that the ambient temperature is in each bin is estimated. If $T_{U}$ and $T_{L}$ are the upper and the lower temperature values defining each bin, $T_{U}$ for one bin is $\mathrm{T}_{\mathrm{L}}$ for the next warmer bin (Markus and Morris, 1980; Olorunmaiye and Ariyo, 1998). The value of the degree-day is a measure of weather related heating and cooling energy needed in the building (Indraganti and Boussaa 2016). Refinements to the bin procedure include the use of coincident wet bulb temperatures to calculate latent loads in each temperature bin as a separate consideration of the internal loads (Stewart, 2001).

Nigeria is in the tropical region where ambient temperatures are high most of the time. Cooling is required to provide human comfort, hence the need for consideration of cooling energy requirement in this study. An example of the use of heating degree-day in a tropical climate is in the field of agriculture. Owing to growing concerns about production and consumption of energy, energy analysis is vital in the design and operation of buildings especially in the selection of a suitable air- conditioning system. Degree-day and bin methods are still widely used in spite of other energy methods such as detailed computer simulations. The most accurate methods for calculating building energy consumption are the most costly because of their intense computational requirements and the expertise needed by the designer or analyst (ASHRAE Fundamentals, 2013). Degree-day and bin methods are the simplest and well established tools for energy analysis. Although energy analysis methods are not yet popular in Nigeria, annual cooling requirements of a specific building in Ilorin were estimated using degree-day and bin methods in this study. In using degree-day concept in the energy analysis, the base temperature considered is $24^{\circ} \mathrm{C}$ which may be the desired indoor temperature.

\section{Analysis Of Data}

Hourly ambient dry bulb temperature data for Ilorin (latitude $8^{0} 26^{\prime} \mathrm{N}$, longitude $4^{0} 29^{\prime} \mathrm{E}$ ) for 15 years (1978-1992) were obtained in printed form from Nigeria Meteorological services Oshodi, Lagos, Nigeria for the purpose of computer analyses.

Degree-day method is a simple method and a well established tool for energy analysis, if the utilization of the building, the efficiency of the Heating, Ventilating and Air-Conditioning (HVAC) equipment, the indoor temperature and the internal heat gains are relatively constant (Bulut et al, 2002). Cooling degreedays were calculated from hourly dry bulb temperature data using the expression: 


$$
C D D=\sum_{i=1}^{n} \frac{1}{24} f\left(T_{0}\right)
$$

where

$$
\begin{aligned}
& \mathrm{f}\left(\mathrm{T}_{\mathrm{o}}\right)=\mathrm{T}_{\mathrm{o}}-\mathrm{T}_{\mathrm{b}} \text { if } \mathrm{T}_{\mathrm{o}}>\mathrm{T}_{\mathrm{b}} \\
& \mathrm{f}\left(\mathrm{T}_{\mathrm{o}}\right)=0 \text { if } \mathrm{T}_{\mathrm{o}} \leq \mathrm{T}_{\mathrm{b}}
\end{aligned}
$$

$\mathrm{T}_{\mathrm{o}}=$ hourly dry bulb (outdoor) temperature in ${ }^{\circ} \mathrm{C}$

$\mathrm{T}_{\mathrm{b}}=$ base temperature in ${ }^{\circ} \mathrm{C}$

$\mathrm{n}=$ number of hours in the period over which cooling degree-day is calculated

$\mathrm{CCD}=$ Cooling Degree-Day

A single cooling degree-day model was developed for two locations in Nigeria, namely; Ilorin and Ikeja by Ariyo (1997): where

$$
\mathrm{CDD}=\sigma_{\mathrm{m} \mathrm{N}}{ }^{3 / 2}\left(0.081546+\mathrm{h}_{\mathrm{b}}{ }^{*} / 2+1 / 8.50 \ln \cosh \left(4.25 \mathrm{~h}_{\mathrm{b}}{ }^{*}\right)\right)
$$

$$
\mathrm{h}_{\mathrm{b}}{ }^{*}=\left(\mathrm{T}_{\mathrm{m}, \mathrm{av}}-\mathrm{T}_{\mathrm{b}}\right) / \sigma_{\mathrm{m}} \sqrt{\mathrm{N}}
$$

$\mathrm{N}=$ number of days in the month

$\mathrm{T}_{\mathrm{m}, \mathrm{av}}=$ monthly average daily ambient temperature

$\sigma_{\mathrm{m}}=$ standard deviation of $\mathrm{T}_{\mathrm{m}, \mathrm{av}}$

$\mathrm{T}_{\mathrm{b}}=$ base temperature

Addition of the monthly cooling degree-days gives the annual total cooling degree-days shown in Tables 1 and

2. Using CDD, annual cooling requirement, $\mathrm{Q}_{\mathrm{c}}$ in terms of $\mathrm{kWh}$ can be calculated as

$$
Q_{c}=\frac{K_{t o t}}{C O P} C D D \frac{24}{1000}
$$

Where

$\mathrm{K}_{\text {tot }}=$ total heat transfer coefficient of the building in $\mathrm{W} /{ }^{\circ} \mathrm{C}$

$\mathrm{COP}=$ Coefficient Of Performance of the cooling equipment.

Monthly and annual cooling degree-days from hourly temperatures and model for base temperature of 24, 25, $26,27,28,29$ and $30^{\circ} \mathrm{C}$ respectively are shown in Tables 1 and 2 . For a base temperature of $24^{\circ} \mathrm{C}$, from Table 1 , the highest cooling degree-day occurs in March i.e. $156.4^{\circ} \mathrm{C}$-days. From the study by Ariyo (1997), March has the highest mean maximum temperature, hence its highest cooling requirement. Variation of annual cooling

\begin{tabular}{|c|c|c|c|c|c|c|c|c|c|c|c|c|c|}
\hline Month & Jan & Feb & Mar & Apr & May & Jun & Jul & Aug & Sep & Oct & Nov & Dec & Annual Total \\
\hline \multicolumn{14}{|l|}{$\begin{array}{l}\text { Base } \\
\text { Temp. } \\
\left({ }^{\circ} \mathrm{C}\right)\end{array}$} \\
\hline 24 & 99.7 & 134.2 & 156.4 & 128.9 & 97.8 & 65.3 & 39.2 & 34.2 & 43.7 & 68.4 & 96.1 & 87.6 & 1051.5 \\
\hline 25 & 80.7 & 111.8 & 129.6 & 104.3 & 75.6 & 47.4 & 25.9 & 21.8 & 30.5 & 51.8 & 77.0 & 69.8 & 826.2 \\
\hline 26 & 64.3 & 92.0 & 106.0 & 83.0 & 57.4 & 33.1 & 15.8 & 12.7 & 20.2 & 38.2 & 61.0 & 54.9 & 638.6 \\
\hline 27 & 50.2 & 74.8 & 86.0 & 65.2 & 42.3 & 21.6 & 8.4 & 6.4 & 12.2 & 27.1 & 47.5 & 42.2 & 483.9 \\
\hline 28 & 38.0 & 59.7 & 68.6 & 50.3 & 29.9 & 12.8 & 3.6 & 2.6 & 6.3 & 18.0 & 36.0 & 31.4 & 357.2 \\
\hline 29 & 27.7 & 46.6 & 53.6 & 37.5 & $5 \quad 19.7$ & 6.4 & 1.1 & 0.8 & 2.6 & 10.8 & 26.1 & 22.2 & $2 \quad 255.1$ \\
\hline 30 & 19.0 & 35.0 & 40.5 & 26.7 & $7 \quad 11.8$ & 2.4 & 0.2 & 0.1 & 0.7 & 5.5 & 17.6 & 14.5 & $\begin{array}{ll}5 & 174.0\end{array}$ \\
\hline
\end{tabular}
degree-days with base temperature is shown in figure 1 . The value of cooling degree-days decreases significantly with increase in base temperature. Comparison of cooling degree-days i.e. measured minus values predicted with the model is shown in Table 3 .

Table 1 Cooling Degree-Days $\left({ }^{\circ} \mathrm{C}-\right.$ Days) Calculated from Measured Data by Summing up Values of (Hourly Temp.-base Temp.)/ 24 which are greater than zero for Ilorin. 
Table 2 Cooling Degree-Days $\left({ }^{\circ} \mathrm{C}\right.$-Days) Calculated from Model for Ilorin.

\begin{tabular}{|c|c|c|c|c|c|c|c|c|c|c|c|c|c|}
\hline Month & h Jan & $\mathrm{Feb}$ & Mar & Apr & May & Jun & Jul & Aug & Sep & Oct & Nov & Dec & Annual Total \\
\hline \multicolumn{14}{|c|}{$\begin{array}{l}\text { Base } \\
\text { Temp. } \\
\left({ }^{\circ} \mathrm{C}\right)\end{array}$} \\
\hline 24 & 101.1 & 137.0 & 161.2 & 133.6 & 100.5 & 64.3 & 36.6 & 33.1 & 43.8 & 70.7 & 102.1 & 91.5 & 1075.5 \\
\hline 25 & 81.1 & 114.0 & 134.6 & 107.9 & 76.2 & 43.8 & 21.1 & 18.7 & 27.9 & 50.8 & 80.8 & 72.4 & 829.3 \\
\hline 26 & 63.7 & 92.8 & 109.7 & 84.3 & 55.1 & 27.9 & 11.2 & 9.8 & 16.6 & 34.9 & 62.2 & 56.1 & 624.3 \\
\hline 27 & 49.0 & 73.8 & 87.2 & 63.5 & 37.9 & 16.6 & 5.6 & 4.9 & 9.5 & 23.0 & 46.6 & 42.5 & 460.1 \\
\hline 28 & 37.0 & 57.3 & 67.3 & 46.0 & 24.9 & 9.5 & 2.7 & 2.3 & 5.2 & 14.7 & 34.0 & 31.7 & 332.6 \\
\hline 29 & 27.5 & 43.4 & 50.5 & 32.0 & 15.7 & 5.2 & 1.3 & 1.1 & 2.8 & 9.1 & 24.2 & 23.2 & 236.0 \\
\hline 30 & 20.1 & 32.2 & 36.9 & 21.6 & 9.6 & 2.8 & 0.6 & 0.5 & 1.5 & 5.5 & 17.0 & 16.8 & 165.1 \\
\hline
\end{tabular}

Table 3 Comparison of Cooling Degree-Days ( ${ }^{\circ} \mathrm{C}$-Days) (Measured minus Values Predicted with the Model) for Ilorin .

\begin{tabular}{|l|l|l|l|l|l|l|l|}
\hline Base Temp. $\left({ }^{0} \mathrm{C}\right)$ & 24 & 25 & 26 & 27 & 28 & 29 & 30 \\
\hline Differences (Degree - Days) & 24.0 & 3.1 & 14.3 & 23.8 & 24.6 & 19.1 & 8.9 \\
\hline
\end{tabular}

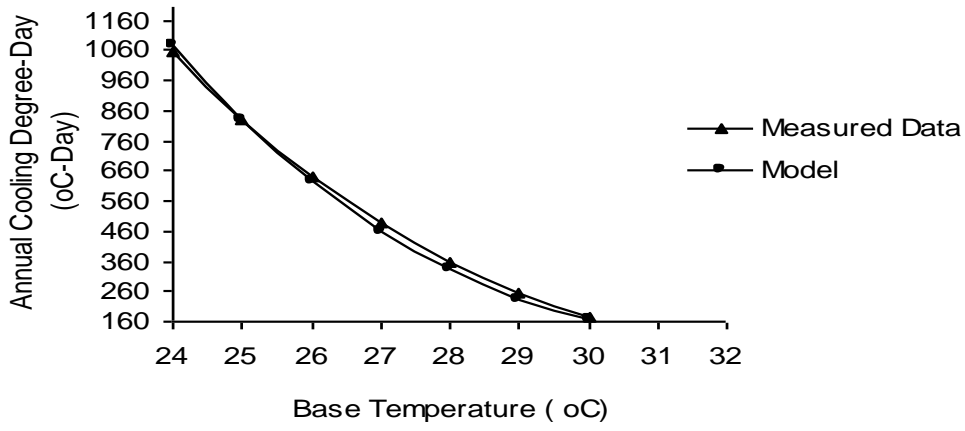

Fig. 1 Variation of Annual Cooling Degree-Days with Base Temperatures for Ilorin

Bin data were complied for each month of the year using a bin width of $1^{\circ} \mathrm{C}$ yielding 12 bin data set. The number of hours in each bin was divided by the number of years of data used to get the average bin data for that month. The total number of hours in each monthly average bin data set is equal to 24 (hour/day) $\mathrm{x}$ (number of days in the month). Although there is no precise rule for determining the optimum number of bins, the following rule of thumb was used. If $\mathrm{N}$ is the number of data points and $\mathrm{r}$ is the range of the data, a reasonable interval width $\Delta$ is (Lewis, 1987)

$$
\Delta \approx \mathrm{r}\left[1+3.3 \log _{10}(\mathrm{~N})\right]^{-1}
$$

Equation (6) was used to determine the bin width of $1^{\circ} \mathrm{C}$ used to compute the bin data.

Bin method is used in many applications if the utilization of the building, efficiency of the HVAC equipment, base temperature and the total heat transfer coefficient of the building are not constant. Since bin method is based on hourly weather data rather than daily averages, it is more accurate than the degree-day method (Bulut et al, 2002). Bin method is based on calculation of energy consumption for different values of outdoor temperature $T_{o}$ and multiplied by the number of hours $\mathrm{N}_{\text {bin }}$ in the temperature interval (bin) centered around that temperature:

$$
Q_{b i n}=N_{b i n} \frac{K_{t o t}}{C O P}\left(T_{o}-T_{b}\right)^{+}
$$

The plus superscript on the parenthesis of Equation (7) indicates that only positive values are to be counted for cooling. Q Q bin values are calculated separately using Equation (7) for each temperature interval (bin) and summed to obtain total energy consumption: 


$$
Q_{\text {tot }}=\sum_{i=1}^{m} Q_{b i n, i}
$$

where $m$ is the total number of bins.

Bin data computed from hourly ambient dry bulb temperature are presented in Table 4 . As can be seen from the table, the maximum annual total $\mathrm{N}_{\text {bin }}$ value is 1035.3 hours in $23.5^{\circ} \mathrm{C}\left(23^{\circ} \mathrm{C}-24{ }^{\circ} \mathrm{C}\right)$ temperature interval.

Cumulative distribution of annual bin data for Ilorin is shown in figure 2. From the figure, approximate hours of cooling can be read by choosing a base temperature. For example, at a base temperature $\mathrm{T}_{\mathrm{b}}=24{ }^{\circ} \mathrm{C}$, cooling season is 3234 hours.

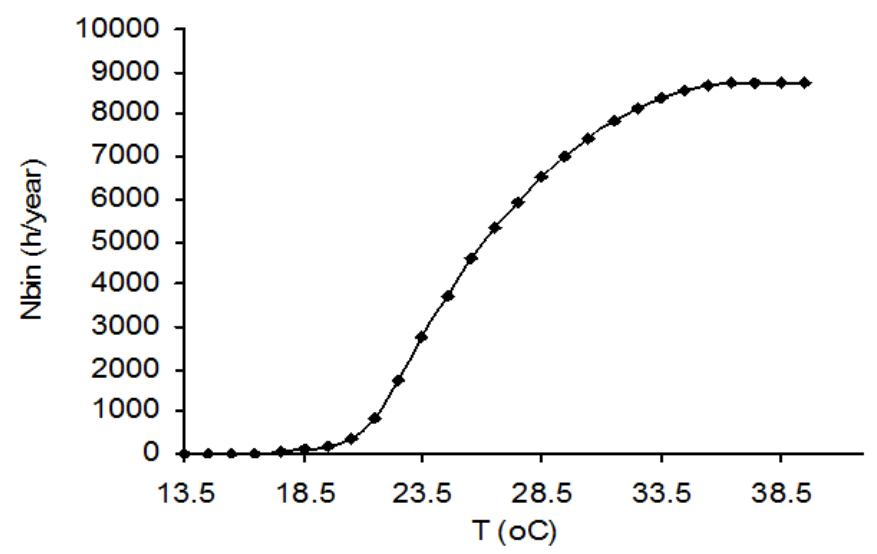

Fig. 2 Cumulative Distribution of Annual Total Bin Data for llorin

\section{Calculation Of Energy Requirements For A Sample Building}

Annual energy requirements of a sample building (workshop) in Ilorin were calculated. The following information relate to the building:

Floor area $=12 \mathrm{~m} \times 6 \mathrm{~m}$

Height $=4.5 \mathrm{~m}$

Air change rate $=1.5$ per hour

$\mathrm{K}_{\mathrm{tot}}=810.1 \mathrm{~W} /{ }^{\circ} \mathrm{C}$

$\mathrm{COP}$ of cooling system $=3.5$

If cooling degree-day of $1051.5^{\circ} \mathrm{C}$-Days is taken for a base temperature $\mathrm{T}_{\mathrm{b}}$ of $24^{\circ} \mathrm{C}$ from Table 1 and inserted into Equation (5), annual cooling energy requirement for the sample building, $\mathrm{Q}_{\mathrm{c}}=5841.05 \mathrm{kWh}$.

With a base temperature, $\mathrm{T}_{\mathrm{b}}$ of $24^{\circ} \mathrm{C}, \mathrm{K}_{\mathrm{tot}}=810.1 \mathrm{~W} /{ }^{\circ} \mathrm{C}$, and reading bin value from Table 4 , annual cooling energy requirement for the building in the entire 24-hour period, $\mathrm{Q}_{\mathrm{c}}=6023.4 \mathrm{kWh}$. Equations (7) and (8) were used to obtain this value. The method adopted in this present study is that of estimating energy requirement for the 24-hour period using the same $\mathrm{K}_{\mathrm{tot}}$ so that the period of occupation can be calculated as a fraction of the total energy requirement. Cooling energy requirement for each bin is given in Table 5.

Table 4 Computed Ambient Temperature Bin Data for Ilorin (Hours)

\begin{tabular}{|c|c|c|c|c|c|c|c|c|c|c|c|c|c|c|c|}
\hline $\begin{array}{l}\text { Bin } \\
\text { Temp } \\
\left({ }^{\circ} \mathrm{C}\right)\end{array}$ & $\begin{array}{l}13- \\
14\end{array}$ & $\begin{array}{l}14- \\
15\end{array}$ & $\begin{array}{l}15 \\
- \\
16 \\
\end{array}$ & $\begin{array}{l}16- \\
17\end{array}$ & $\begin{array}{l}17- \\
18\end{array}$ & $\begin{array}{l}18- \\
19\end{array}$ & $\begin{array}{l}19- \\
20\end{array}$ & $\begin{array}{l}20- \\
21\end{array}$ & $\begin{array}{l}21- \\
22\end{array}$ & $\begin{array}{l}22- \\
23\end{array}$ & $\begin{array}{l}23- \\
24\end{array}$ & $\begin{array}{l}24- \\
25\end{array}$ & $\begin{array}{l}25- \\
26\end{array}$ & $\begin{array}{l}26- \\
27\end{array}$ & $\begin{array}{l}27- \\
28\end{array}$ \\
\hline Jan & 0.4 & 0.9 & 3.4 & 8.9 & 14.1 & 21.9 & 26.5 & 31.5 & 37.0 & 48.6 & 57.4 & 61.3 & 61.1 & 52.4 & 43.1 \\
\hline Feb & 0.0 & 0.0 & 0.1 & 0.0 & 0.9 & 2.1 & 7.2 & 12.9 & 16.2 & 26.0 & 41.3 & 57.5 & 64.1 & 55.1 & 46.0 \\
\hline Mar & 0.0 & 0.0 & 0.0 & 0.0 & 0.0 & 0.0 & 0.1 & 1.5 & 7.2 & 20.1 & 35.9 & 62.2 & 87.4 & 74.5 & 60.8 \\
\hline Apr & 0.0 & 0.0 & 0.0 & 0.0 & 0.0 & 0.0 & 0.0 & 1.5 & 8.4 & 26.5 & 48.9 & 70.8 & 88.2 & 79.2 & 58.5 \\
\hline May & 0.0 & 0.0 & 0.0 & 0.0 & 0.0 & 0.0 & 0.0 & 5.7 & 19.8 & 43.0 & 80.0 & 101.3 & 84.9 & 71.2 & 57.4 \\
\hline Jun & 0.0 & 0.0 & 0.0 & 0.0 & 0.0 & 0.2 & 2.0 & 15.7 & 34.8 & 71.9 & 101.7 & 99.7 & 77.5 & 67.5 & 58.5 \\
\hline Jul & 0.0 & 0.0 & 0.0 & 0.0 & 0.0 & 0.0 & 2.9 & 17.1 & 58.3 & 144.3 & 141.1 & 91.6 & 73.7 & 62.6 & 59.4 \\
\hline Aug & 0.0 & 0.0 & 0.0 & 0.0 & 0.0 & 0.1 & 1.5 & 16.4 & 67.9 & 166.8 & 133.8 & 93.2 & 72.5 & 63.4 & 59.6 \\
\hline Sep & 0.0 & 0.0 & 0.0 & 0.0 & 0.0 & 0.5 & 4.1 & 25.4 & 68.1 & 142.8 & 112.9 & 78.8 & 63.1 & 50.9 & 53.0 \\
\hline Oct & 0.0 & 0.0 & 0.0 & 0.0 & 0.0 & 0.0 & 1.2 & 15.6 & 58.8 & 90.0 & 125.0 & 87.1 & 65.5 & 54.2 & 43.8 \\
\hline Nov & 0.0 & 0.0 & 0.2 & 0.3 & 4.7 & 7.0 & 10.9 & 13.4 & 27.4 & 49.4 & 87.5 & 96.3 & 64.5 & 53.4 & 45.3 \\
\hline Dec & 0.2 & 0.3 & 2.4 & 7.1 & 14.8 & 24.0 & 25.4 & 32.8 & 42.5 & 49.8 & 69.8 & 74.5 & 64.3 & 49.8 & 41.8 \\
\hline $\begin{array}{l}\text { Bin } \\
\text { Total }\end{array}$ & 0.6 & 1.2 & 6.1 & 16.3 & 34.5 & 55.8 & 81.8 & $\begin{array}{l}189 . \\
5\end{array}$ & $\begin{array}{l}446 . \\
4\end{array}$ & 879.2 & $\begin{array}{l}1035 . \\
3\end{array}$ & 974.3 & $\begin{array}{l}866 . \\
8\end{array}$ & 734.2 & $\begin{array}{l}627 . \\
2\end{array}$ \\
\hline
\end{tabular}




\begin{tabular}{|c|c|c|c|c|c|c|c|c|c|c|c|c|c|}
\hline $\begin{array}{l}\text { Bin } \\
\text { Temp. } \\
\left({ }^{\circ} \mathrm{C}\right)\end{array}$ & $\begin{array}{l}28- \\
29\end{array}$ & $\begin{array}{l}29- \\
30\end{array}$ & $30-31$ & $\begin{array}{l}31- \\
32\end{array}$ & $32-33$ & $33-34$ & $34-35$ & $35-36$ & $\begin{array}{l}36- \\
37\end{array}$ & $\begin{array}{l}37- \\
38\end{array}$ & $\begin{array}{l}38- \\
39\end{array}$ & $\begin{array}{l}39- \\
40\end{array}$ & $\begin{array}{l}\text { Monthly } \\
\text { Total }\end{array}$ \\
\hline Jan & 43.5 & 38.7 & 41.5 & 39.5 & 40.1 & 37.1 & 24.0 & 8.5 & 2.2 & 0.3 & 0.1 & 0.0 & 744.0 \\
\hline Feb & 42.6 & 38.6 & 38.6 & 38.9 & 39.1 & 42.0 & 42.2 & 36.1 & 19.2 & 5.1 & 0.2 & 0.0 & 672.0 \\
\hline Mar & 52.7 & 45.7 & 46.8 & 41.5 & 43.6 & 44.2 & 45.9 & 37.6 & 23.8 & 10.7 & 1.6 & 0.2 & 744.0 \\
\hline Apr & 50.6 & 46.2 & 46.6 & 46.2 & 47.8 & 40.8 & 29.2 & 16.3 & 9.1 & 4.4 & 0.8 & 0.0 & 720.0 \\
\hline May & 55.4 & 55.2 & 57.1 & 52.4 & 33.0 & 14.9 & 7.5 & 3.2 & 1.4 & 0.5 & 0.1 & 0.0 & 744.0 \\
\hline Jun & 58.2 & 57.7 & 47.0 & 23.2 & 3.7 & 0.5 & 0.2 & 0.0 & 0.0 & 0.0 & 0.0 & 0.0 & 720.0 \\
\hline Jul & 50.9 & 30.1 & 10.9 & 1.1 & 0.0 & 0.0 & 0.0 & 0.0 & 0.0 & 0.0 & 0.0 & 0.0 & 744.0 \\
\hline Aug & 39.5 & 21.3 & 7.2 & 0.8 & 0.0 & 0.0 & 0.0 & 0.0 & 0.0 & 0.0 & 0.0 & 0.0 & 744.0 \\
\hline Sep & 48.4 & 42.8 & 21.7 & 6.8 & 0.6 & 0.1 & 0.0 & 0.0 & 0.0 & 0.0 & 0.0 & 0.0 & 720.0 \\
\hline Oct & 45.8 & 48.7 & 48.8 & 35.1 & 16.1 & 6.3 & 1.8 & 0.2 & 0.0 & 0.0 & 0.0 & 0.0 & 744.0 \\
\hline Nov & 33.3 & 37.1 & 37.2 & 46.6 & 43.9 & 35.7 & 19.0 & 6.1 & 0.8 & 0.0 & 0.0 & 0.0 & 720.0 \\
\hline Dec & 36.7 & 37.8 & 35.5 & 43.8 & 45.5 & 30.3 & 11.8 & 3.0 & 0.1 & 0.0 & 0.0 & 0.0 & 744.0 \\
\hline $\begin{array}{l}\text { Bin } \\
\text { Total }\end{array}$ & 557.6 & 499.9 & 438.9 & 375.9 & 313.4 & 251.9 & 181.6 & 111.0 & 56.6 & 21.0 & 2.8 & 0.2 & 8760.0 \\
\hline
\end{tabular}

Table 5 Cooling Energy Requirement for each Temperature Bin for Ilorin

\begin{tabular}{|c|c|c|c|c|c|c|c|c|c|c|c|c|c|c|c|}
\hline $\begin{array}{l}\text { Bin } \\
\text { Temp }\left({ }^{\circ} \mathrm{C}\right)\end{array}$ & $\begin{array}{l}13- \\
14\end{array}$ & $\begin{array}{l}14- \\
15\end{array}$ & $\begin{array}{l}15- \\
16\end{array}$ & $\begin{array}{l}16- \\
17\end{array}$ & $\begin{array}{l}17- \\
18\end{array}$ & $\begin{array}{l}18- \\
19\end{array}$ & $\begin{array}{l}19- \\
20\end{array}$ & $\begin{array}{l}20- \\
21\end{array}$ & $\begin{array}{l}21- \\
22\end{array}$ & $\begin{array}{l}22- \\
23\end{array}$ & $\begin{array}{l}23- \\
24\end{array}$ & $24-25$ & $25-26$ & $26-27$ & $27-28$ \\
\hline
\end{tabular}

\begin{tabular}{|c|c|c|c|c|c|c|c|c|c|c|c|c|c|}
\hline $\begin{array}{l}\text { Bin } \\
\text { Temp }\left({ }^{\circ} \mathrm{C}\right)\end{array}$ & $28-29$ & $29-30$ & $30-31$ & $31-32$ & $32-33$ & $33-34$ & $34-35$ & $35-36$ & $36-37$ & $\begin{array}{l}37- \\
38 \\
\end{array}$ & $\begin{array}{l}38- \\
39 \\
\end{array}$ & $\begin{array}{l}39- \\
40\end{array}$ & Total \\
\hline $\begin{array}{l}\text { Energy } \\
\text { Requirement } \\
(\mathrm{kWh})\end{array}$ & 580.8 & 636.4 & 660.3 & 652.5 & 616.6 & 553.9 & 441.3 & 295.5 & 163.8 & 65.6 & 9.4 & 0.7 & 6023.4 \\
\hline
\end{tabular}

\section{Discussion Of Results}

Indoor temperature of $24^{\circ} \mathrm{C}$ was chosen in the calculation of cooling energy requirements using both degree-day and bin methods since this is also the design indoor temperature. The values obtained from bin method are more realistic than those obtained from degree-day method since bin method is based on hourly data rather than daily mean temperatures. It can be seen from Table 1 that values of degree-days change significantly with base temperatures and this affects cooling energy requirement directly; this is also valid for bin method. In the energy calculation using bin method, evaluation was made for the entire 24-hour period using the same $\mathrm{K}_{\text {tot }}$ so that cooling energy for occupied periods can be calculated as a fraction of the total energy requirement. It is considered to be a less cumbersome method and could result in a good approximation.

Annual cooling energy requirement using degree-day method is $5841.05 \mathrm{kWh}$ whereas that of bin method is $6023.4 \mathrm{kWh}$.

\section{Conclusions}

In this study, base temperatures of $24,25,26,27,28,29$ and $30^{\circ} \mathrm{C}$ were used to calculate cooling degreedays for Ilorin. Bin width of $1^{\circ} \mathrm{C}$ was used to compute bin data from the long-term ambient hourly dry bulb temperature data. The results are presented in tables and figures.

Annual energy requirements of a sample building (workshop) in Ilorin were estimated using degreeday and bin values obtained in this study. Cooling energy requirement obtained from bin method is higher than that of degree-day method; it could be that bin method has slightly overestimated the energy requirement whereas the degree-day method has underestimated the energy. The energy requirement could be somewhere between the two values. These methods can be employed for cooling energy estimation when annual degree-day and bin values are available and physical and thermal properties of the building are known (Bulut et al., 2002).

Cooling degree-day and bin values for Ilorin can also be used for places in the middle belt of Nigeria and elsewhere having similar weather pattern, for the purpose of cooling energy estimation.

\section{References}

[1]. Ariyo, D.O. (1997). Models for ambient dry bulb temperature and relative humidity statistics related to building cooling loads for Ilorin and Ikeja. M.Eng. Project report, Department of Mechanical Engineering, University of Ilorin.

[2]. ASHRAE (2013). Handbook of fundamentals., S.I. Edition, American Society of Heating, Refrigerating and Air-Conditioning Engineers, Atlanta, GA. 
[3]. Bulut,H., Buyukalaca .O., Yilmaz .T., (2002). Determination and application of the data used in energy estimation methods for Istanbul. English Version. www.eng.harran.edu.tr

[4]. Erbs, D.G., (1984). Models and applications for weather statistics related to building heating and cooling loads. Ph.D. Thesis, University of Wisconsin-Madison.

[5]. Indraganti, M. (2016). A method to estimate the heating and cooling degree-days for different climatic zones of

[6]. Saudi Arabia. Building services engineering research and technology, 1-24. DOI: 10.1177/0143624416681383

[7]. Lewis, E.E. (1987). Introduction to reliability engineering. $\mathrm{I}^{\text {st }}$ Edition. John Wiley \& Sons, New York.

[8]. Markus, T.A., Morris, E.N. (1980). Buildings, climate and energy. ${ }^{\text {st }}$ Edition. Pitman Publishing Limited, London.

[9]. Olorumaiye, J.A., Ariyo D.O. (1998). The relationship between cooling degree-days and base temperatures for southern Nigerian cities", A.M.S.E., Modeling, Measurements and Control. Vol.66, No.1, pp21-31, Tassin, France.

[10]. Stewart, M.E. (2001). Validation of a simplified building cooling load model using a complex computer simulation model. M. Sc Thesis in Mechanical engineering. Virginia Polytechnic Institute and State University. 